https://dx.doi.org/10.4314/ijs.v22i3.2

Ife Journal of Science vol. 22, no. 3 (2020)

\title{
PALYNOSTRATIGRAPHIC AND PALYNOFACIES ANALYSIS OF X AND Y WELLS, OFFSHORE NIGER DELTA, NIGERIA
}

\author{
${ }^{1}$ Fadiya, S. L., ${ }^{1}$ Ogunleye, S. O., ${ }^{2}$ Oyelami A. B. and ${ }^{3}$ Aroyewun, F. R. \\ ${ }^{1}$ Department of Geology, Obafemi Awolowo University, Ile - Ife, Osun State. Nigeria. \\ ${ }^{2}$ GEC Energy Solutions Limited, Ikeja, Lagos \\ ${ }^{3}$ Crystal Age Limited, Ikorodu, Lagos. \\ *Corresponding author's e-mail: slfadiya@oauife.edu.ng; fadiyalawrence@yahoo.co.uk \\ Telephone: (+234- 80333-20230; 234-80278-36738) \\ (Received: 4th May, 2020; Accepted: 28th September, 2020)
}

\section{ABSTRACT}

\begin{abstract}
A detailed palynostratigraphic and palynofacies study was carried out on two shallow offshore wells, codenamed Well X and Well Y, from the Niger Delta Basin, Nigeria. The study is aimed at establishing the age and palaeoenvironment of the sedimentary sequences penetrated by the wells. Standard palynological/palynofacies laboratory procedures were used to free the palynomorphs and palynomacerals from the embedding matrices. Prepared palynological slides were studied using the Leitz Ortholux II transmitted light microscope. The palynofloral assemblages recorded from the two well sequences include well-preserved palynomorphs such as Zonocostites ramonae, Monoporites annulatus, Retitricolporites irregularis, Cyperaceaepollis sp., Echitricolporites spinosus and Nymphaeapollis clarus among others. The recognition of diagnostic pollen of Cyperaceaepollis sp. and Nymphaeapollis clarus as well as the associated palynomorph assemblage aided the delineation of the well sequences into the P830, P840-P850 and P860 subzones of the P800 palynological zone in the late Miocene. The relative abundance of particulate organic matter (Amorphous Organic Matter (AOM), Phytoclasts and Palynomorphs) revealed the delineation of three palynofacies assemblages, PF-A, PF-B and PF-C, suggesting three distinct paleoenvironments of deposition. These paleoenvironments range from distal shelf through marginal to proximal with varying conditions from oxic, suboxic to anoxic, thus suggesting marginal marine to coastal deltaic environments of deposition for the sedimentary sequences penetrated by the two wells.
\end{abstract}

Keywords: Late Miocene, Niger Delta, Paleoenvironment, Palynostratigraphy, Palynofacies.

\section{INTRODUCTION}

Palynomorphs are important microfossils useful in age and zonal delineation of rock strata into biostratigraphic units aimed at correlating depositional sequences as well as for paleoenvironmental interpretation (Adegoke, 2002). The occurrence of palynomorphs in diverse environments, from the continental to marine sediments, confers additional advantage on palynology over other biostratigraphic tools by facilitating strata correlation across the environments (Christopher and Goodman, 1996; Traverse, 2008).

The concept of palynofacies was developed over five decades ago when attention shifted to the variation in the composition of organic facies associated with different rock types leading to rapid expansion of research in organic facies (Batten, 1982). The word palynofacies was first used by Combaz (1964) to distinguish organic petrology from coal petrology and palynology. Palynofacies has also been defined as the total assemblage of microscopic organic constituents recovered from laboratory maceration processes on carbonates and silicates using Hydrochloric acid $(\mathrm{HCl})$ and Hydrofluoric acid (HF) which are concentrated and mounted on glass slides. Although this is a generally acceptable definition, slight modifications to it have been made by different authors (Tranverse, 2008; Powell et al., 1990; Batten and Stead, 2005). In a contemporary definition, Tyson (1995) refers to palynofacies as a distinctive assemblage of palynological organic matter characterizing a particular environment. Palynofacies analysis involves the identification of palynomorphs, plant debris and amorphous particles, their absolute and relative proportion, size spectra and state of preservation (Combaz 1964, 1980). Palynofacies analysis has assumed greater significance in oil exploration by virtue of its contributions to reconstruction of depositional environments which aid in the general evaluation of the hydrocarbon potential of sedimentary basins (Batten, 1982). Palynofacies analysis is being effectively used as a 
screening technique in oil typing by providing qualitative or semi-qualitative control on geochemical interpretations for source rock potentials (Tyson, 1993).

Tyson (1993) related three key particulate organic matter: amorphous organic matter, phytoclasts and palynomorphs using ternary diagram to interpret different environments of deposition. $\mathrm{He}$ used this to establish nine different palynofacies fields with each corresponding to a different environment of deposition (Figure 1). Subsequently, Rocanglia and Kuijpers (2006) revised the palynofacies model of Tyson (1993) by substituting the palynomorph end-member of the ternary diagram with marine species (foraminifera, dinoflagellate cysts, acritarchs and other marine algae) while retaining the other two ends (amorphous organic matter and phytoclasts). The revised model, according to them, has the potential to provide information on changes in distance from the shore, redox status and terrestrial/fresh water influx at high latitudes on the continental margins on the basis of changes of palynofacies assemblage in sediments.

The major explanation for the success of palynofacies application in solving geological problems is its inter-disciplinary nature and the fact that it forms a natural interface between other fields of geosciences. As significant as the application of palynofacies is in petroleum evaluation, published information on palynofacies studies on the Niger Delta basin are few. These are limited to the efforts of Oyede (1992), Oboh et al. (1992), Oboh (1995) and Odedede et al. (2012). In order to fill this gap in the palynofacies studies of the basin, this present study is aimed at identifying the palynofloral and palynofacies components in the $\mathrm{X}$ and $\mathrm{Y}$ wells towards determining the age and inferring the depositional environments of the sediments.

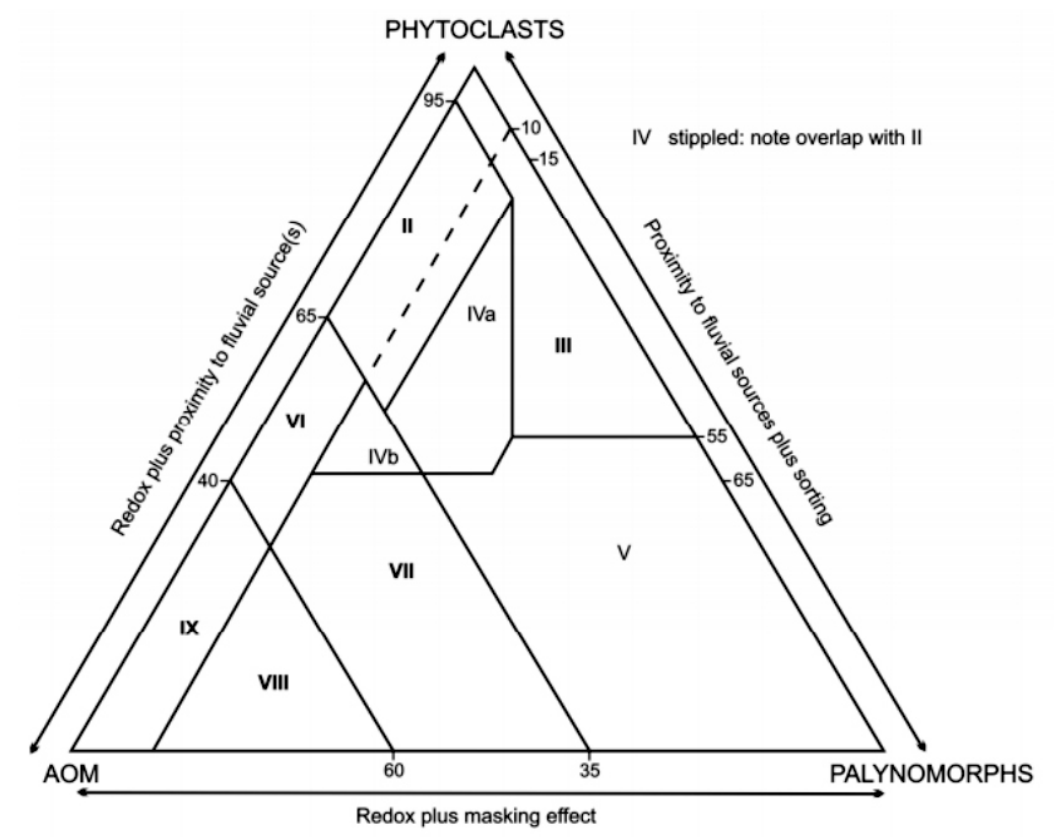

Figure 1: Ternary Kerogen Diagram (after Tyson, 1993).

Field I = highly proximal shelf or basin; Field II = marginal dysoxic-anoxic basin; Field III = heterolithicoxic shelf (proximal shelf); Field IV = shelf to basin transition; Field $\mathrm{V}=$ muddominated oxic shelf (distal shelf); Field VI = proximal suboxic-anoxic shelf; Field VII $=$ distal dysoxic-anoxic shelf; Field VIII = distal dysoxicoxic shelf; Field IX = distal suboxic-anoxic basin.

\section{GEOLOGY OF THE NIGER DELTA}

The Tertiary Niger Delta is situated in the Gulf of Guinea on the west coast of Central Africa (Fig.1). It lies between latitude $04^{\circ} \mathrm{N}$ and $06^{\circ} \mathrm{N}$ and Longitude $003^{\circ}$ and $009^{\circ} \mathrm{E}$ in the southern part of Nigeria. It is bounded in the west by the Benin flank, in the East by the Calabar flank and in the south by the Gulf of Guinea. Its northern margin transects several older Cretaceous tectonic 
elements (Fig. 2) such as the Abakaliki anticlinorium and the Afikpo syncline (Stoneley, 1966; Burke et al., 1972 and Ejedawe, 1981). The Niger Delta, from the Eocene to the present has prograded southwestward forming depobelts that represent the most active portion of the delta at each stage of its development (Doust and Omatsola, 1990). These depobelts form one of the largest regressive deltas in the world with an area of about $300,000 \mathrm{~km}^{2}$ (Kulke, 1995) and a sediment volume of $500,000 \mathrm{~km}^{2}$ (Hospers, 1971). The regressive clastic sequence is believed to reach an approximate thickness of 10,000 metres in the basin depocenter.

The evolution of the Niger Delta commenced during the early Cretaceous after the separation of the African and South American continents. According to Burke et al., (1972), this event was initiated by the presence of a RRR-triple junction at the present site of the delta.
The Niger Delta is a regressive sequence of clastic sediments developed in a series of offlap cycles. This is demonstrated in all the deep wells in the basin alongside with a tripartite lithostratigraphic succession (Doust and Omatsola, 1990). The base of the sequence consists of massive and monotonous marine shales. This grades upward into interbedded shallow-marine and fluvial sands, silts and clays representing a typical paralic facies. The uppermost part of the sequence is a massive non marine section (Doust and Omatsola, 1990). These sequences represent the sediments of the marine, transitional and continental environments as would be expected of an advancing delta such as that of River Niger (Short and Stauble, 1967). The overall sequence is strongly diachronous as in all deltas (Doust Omatsola, 1990). Three main formation names have been assigned to correspond to the tripartite sequence of the Niger Delta. These are the Akata, Agbada and Benin Formations in ascending order (Short and Stauble, 1967; Avbovbo, 1978).

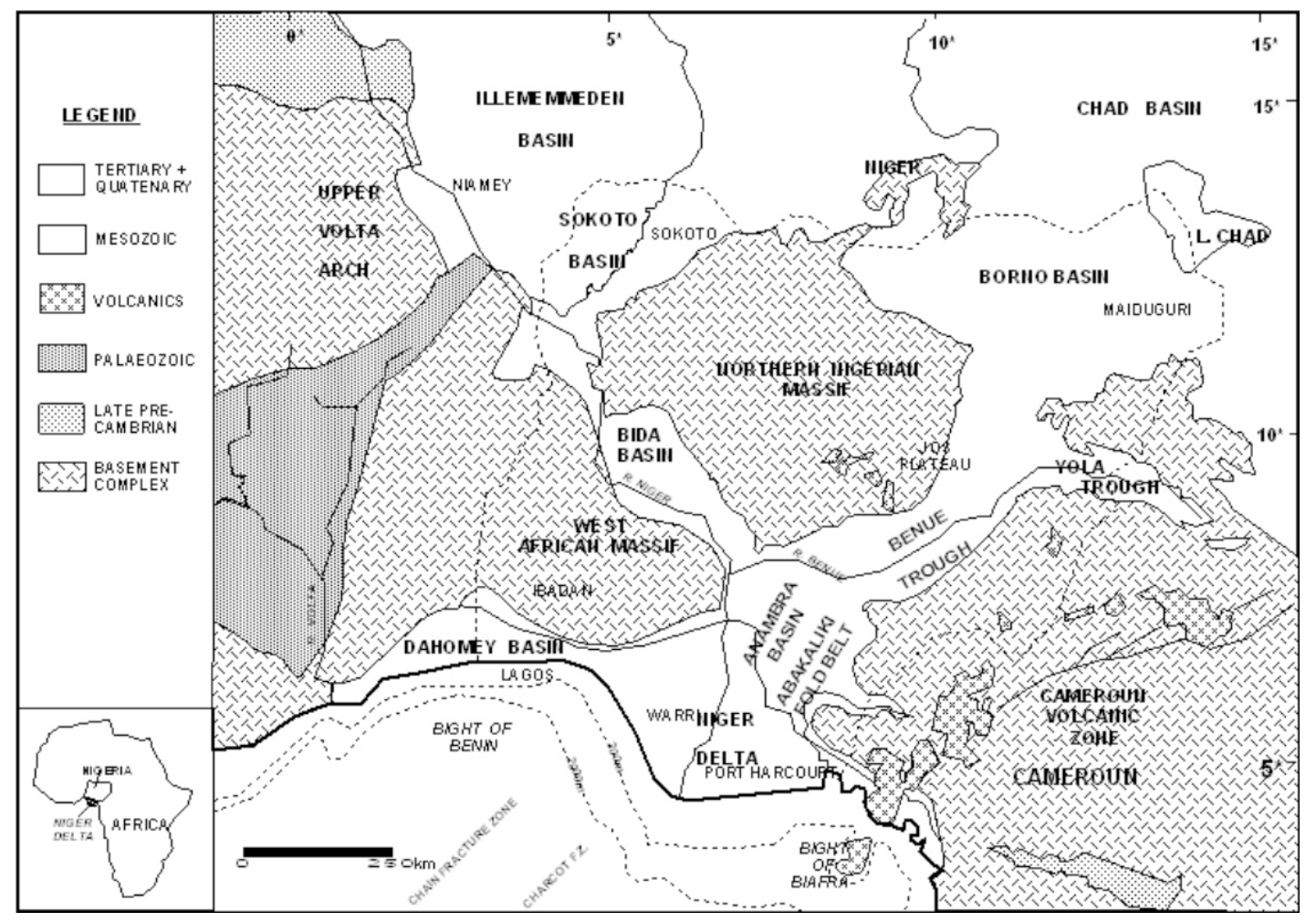

Figure 2: Simplified geologic map of Nigeria and surroundings showing the location of the Niger Delta (modified from Whiteman, 1982 and Allen, 1965) 
The lithofacies of the Agbada Formation is composed of shales, clays, and silts and a few streaks of sand possibly of turbiditic origin. It is known to be rich in microfauna (Doust and Omatsola, 1990). It is believed that the shales of Akata Formation is the source rock for hydrocarbon in the Niger Delta (Ekweozor and Daukoru, 1984). The shales crop out offshore in diapirs along the continental slope and onshore in the northeastern part of the delta where they are known as Imo shale. The Akata Formation is a marine sequence which was laid down in front of the advancing delta during the Eocene to Recent times (Short and Stauble, 1967).

The Agbada Formation is represented by an alternation of sands and shales as well as silts and clays in various proportion and thicknesses. Short and Stauble (1967) recognized an upper sandstone-shale unit composed mainly of sandstone and a lower unit made predominantly of thicker shale units and alternating thinner units of sandstone. The environment of deposition has been found to be of delta front, delta topset and fluvio-deltaic. The age of the formation ranges from Eocene to Pleistocene (Doust and Omatsola, 1990). This formation forms the hydrocarbon prospective sequence in the Niger Delta with sands as reservoirs and the shales contributing as source rocks (Frankl and Cordry, 1967; Short and Stauble, 1967).

The Benin Formation consists of predominantly massive, highly porous, freshwater-bearing sandstone with local thin shale interbeds which are considered to be of braided stream origin. The sands and sandstones which are dominantly of quartz and potash feldspars (Avbovbo, 1978) are coarse-grained, angular to subangular and poorly sorted. Accessory minerals include yellowish brown limonite coatings and lignite. The sand:shale ratio is considered as an important value in separating the Benin Formation from the underlying paralic Agbada Formation (Doust and Omatsola, 1990).

Oil and gas are trapped by both rollover anticlines and by growth fault closures, the predominant reservoirs being the sands of the Agbada Formation. All commercial production of oil in the Tertiary Niger delta is thus from the deltaic sandstones of the Agbada Formation while the Benin and Akata Formations contain only several oil-shows and gas stringers.

\section{MATERIALS AND METHOD}

An aggregate total number of one hundred and twenty (120) ditch cuttings from intervals $2105-$ $3305 \mathrm{~m}$ of well X and $1000-2220 \mathrm{~m}$ of well $\mathrm{Y}$ drilled in the shallow offshore Niger Delta were utilized for this study. The shallow offshore area of the Niger Delta where the studied wells were located is shown in Figure 3 as the actual locations of the wells were not made available for proprietary reasons.

Twenty-five grams of each sample were subjected to standard palynological maceration procedures of acid dissolution. Concentrated 36\% hydrochloric acid $(\mathrm{HCl})$ was added to remove carbonates while the silicate content was removed with $40 \%$ hydrofluoric acid (HF). Heavy liquid separation of the organic content was ensured by adding zinc bromide $\left(\mathrm{ZnBr}_{2}\right)$ solution following Faegri and Iversen (1989) method. The residues for palynomorph analysis were filtered through 5 $\mu \mathrm{m}$ sieve before oxidizing with nitric acid $\left(\mathrm{HNO}_{3}\right)$. Thorough mixture of the samples with the chemicals was ensured at critical maceration stages by centrifugation at high speed. However, unoxidized residue for palynofacies was separated prior to sieving and oxidation. Final residue was mixed thoroughly with $100 \%$ glycerin and put in a labelled vial. About $20 \mathrm{ml}$ of the mixture was mount strewn on a $32 \mathrm{~mm}$ x $22 \mathrm{~mm}$ cover slip and mounted on a $72 \times 22 \mathrm{~mm}$ glass slide using Norland Optical adhesive mounting medium under the UV light. The same mounting process was adopted for the unoxidized palynofacies slide preparation.

Palynological analysis of the prepared slides was carried out with the aid of a Leitz Ortholux II transmitted light microscope with a 25 objective lens as well as x100 objective lens for detailed identification of palynomorphs. The unoxidized slides were also scanned for the particulate organic matter. Relevant bibliographic references consulted include Germeeraad et al. (1968) and Evamy et al. (1978). 


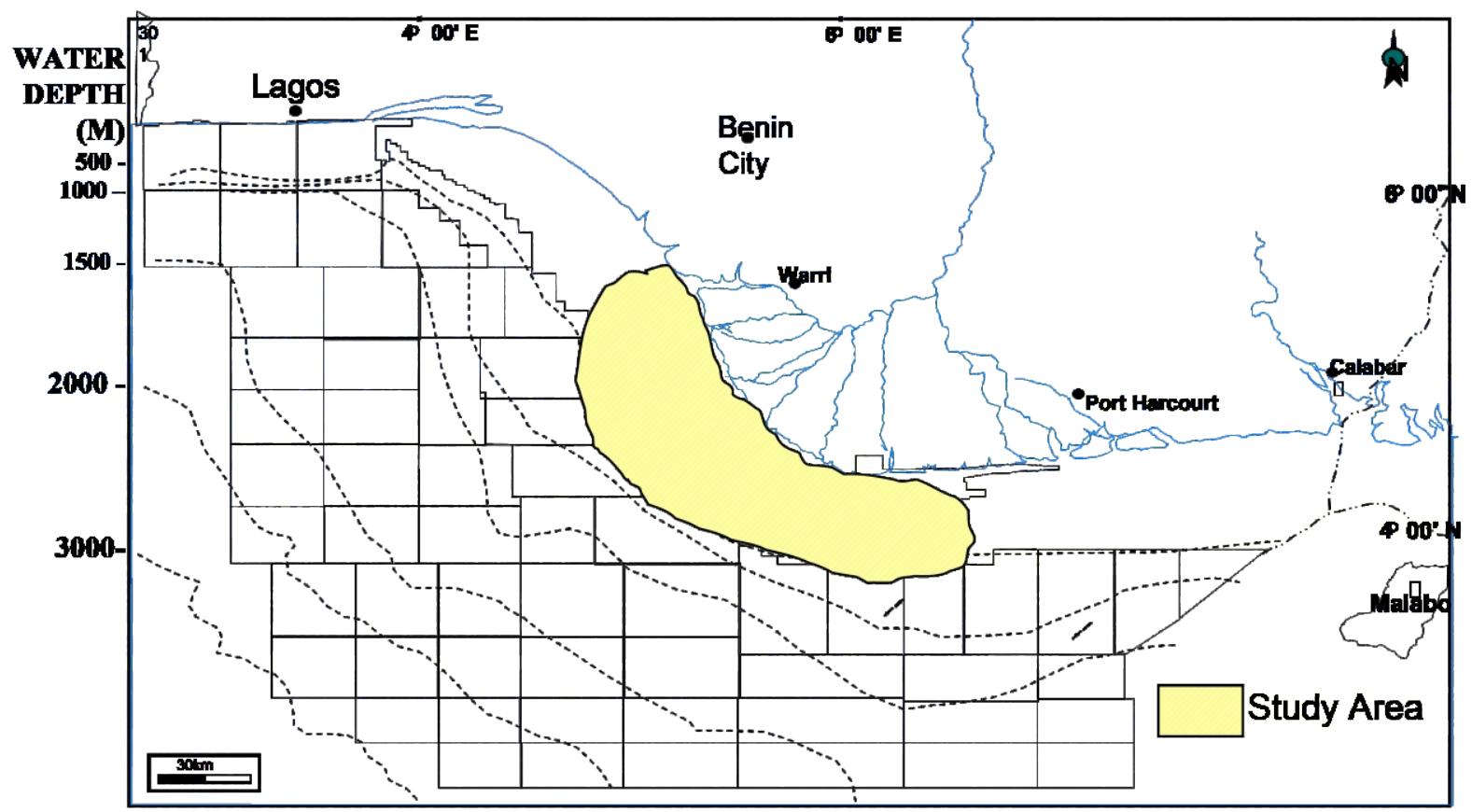

Figure 3: Map of the Niger Delta showing the Niger Delta shallow offshore area where the studied wells were located.

\section{RESULTS AND DISCUSSION}

\section{Lithostratigraphy}

Interpreted lithostratigraphy of wells $\mathrm{X}$ and $\mathrm{Y}$ was made from the gamma ray log as shown in the lithology column of Figures 5 and 6. The $\mathrm{X}$ and $\mathrm{Y}$ wells sequence penetrated an alternating sequence of sand and shale implying that the studied sections of the two wells belong to the Agbada Formation. The sandy lithology is more frequent in the upper part (2125 - $2930 \mathrm{~m})$ of Well X and this implies that the section belong to the upper part of the Agbada Formation. Interval 2930 $3305 \mathrm{~m}$ with thick shaly sections is assigned to the lower part of the Agbada Formation. Similarly, the entire studied section (1020 - $2220 \mathrm{~m})$ of Well-Y with thicker shale units than the sands belongs to the lower part of the Agbada Formation.

\section{Palynostratigraphy}

Fairly abundant, diverse and well-preserved palynomorphs were recovered from the studied sections of Wells $\mathrm{X}$ and $\mathrm{Y}$. The significant and dominant palynomorphs recovered from the sequences penetrated by the two wells include Zonocostites ramonae, Monoporites annulatus, Cyperaceaepollis sp., Retitricolporites irregularis, Nymphaeapollis clarus, Gemmamonoporites sp., Echitricolporites spinous; pteridophyte spores such as Laevigatosporites sp., Verrucatosporites sp. and
Stereiosporites sp. Fungal spores were also recovered with scanty record of the brackish water Botryococcus braunii. Dinocysts are very rare within the studied section of both wells with a single occurrence of Spiniferites sp. at $1060 \mathrm{ft}$ in well Y.

\section{Biozonation and Age Determination}

Most palynomorphs recorded in the wells have close resemblance to species already described in the Niger Delta basin. Biozonation of the strata penetrated by the two wells was largely based on palynofloral assemblage of significant species as well as their stratigraphic distribution with reference to existing zonation schemes of Germeraad et al. (1968) and Evamy et al. (1978). Three palynological subzones of the P800 zone of Evamy et al. (1978) viz; P830, P840-P850 and P860 have been proposed for the analysed intervals of Wells X and Y. The zone corresponds to the Echitricolporites spinosus Zone of Germeraad et al. (1968). Figures 4 and 5 show the micofloral zonations for both Wells $\mathrm{X}$ and $\mathrm{Y}$ respectively. Plate 1 shows the microphotograph of index palynomorph species recovered in the two wells.

The descriptions of the identified palynological zones are provided as follows:

WELL X

Stratigraphic Interval : $\quad 3305-3165 \mathrm{~m}$ 


$\begin{array}{lll}\text { Palynological Subrone } & : & \text { P830 } \\ \text { Age } & : & \text { LateMiocene } \\ \text { Definition: } & & \end{array}$

The base of this subzone probably lies deeper than the last sample analysed at depth $3305 \mathrm{~m}$. Its subzonal top is marked by the quantitative base occurrence of Cyperaceaepollis sp. at $3165 \mathrm{~m}$. From the recognized palynofloral assemblage, a Late Miocene age is assigned to this interval.

\section{Description:}

The rarity of Stereiosporites sp., the boundary marker between the P820 and P830 subzones suggests that the well section is not older than the P830 subzone. Important palynomorphs recorded within the interval include Zonocostites ramonae, Monoporites annulatus and Cyperaceaepollis $\mathrm{sp}$.

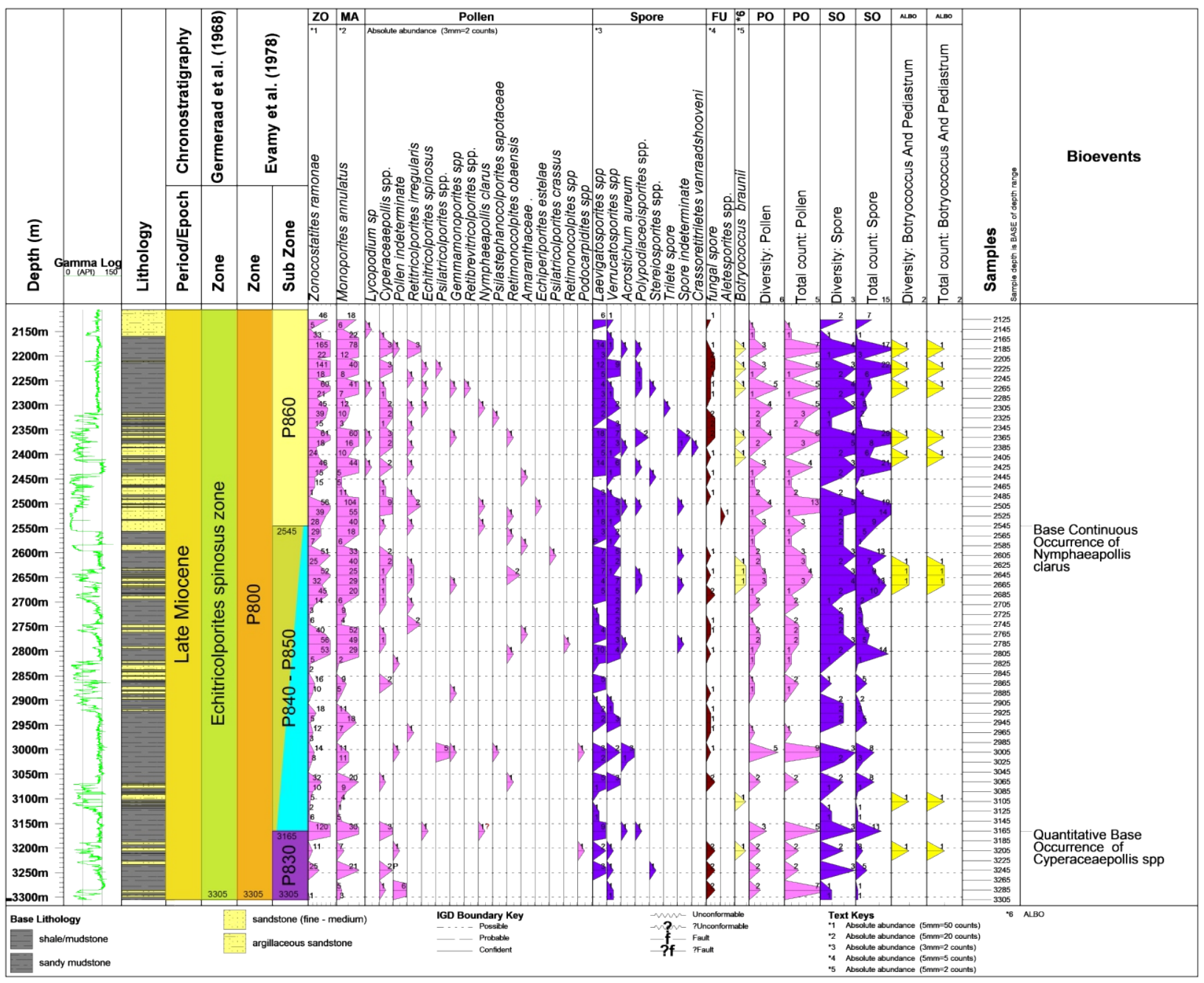

Figure 4: Palynomorphs Distribution and Zonation of Well X. 


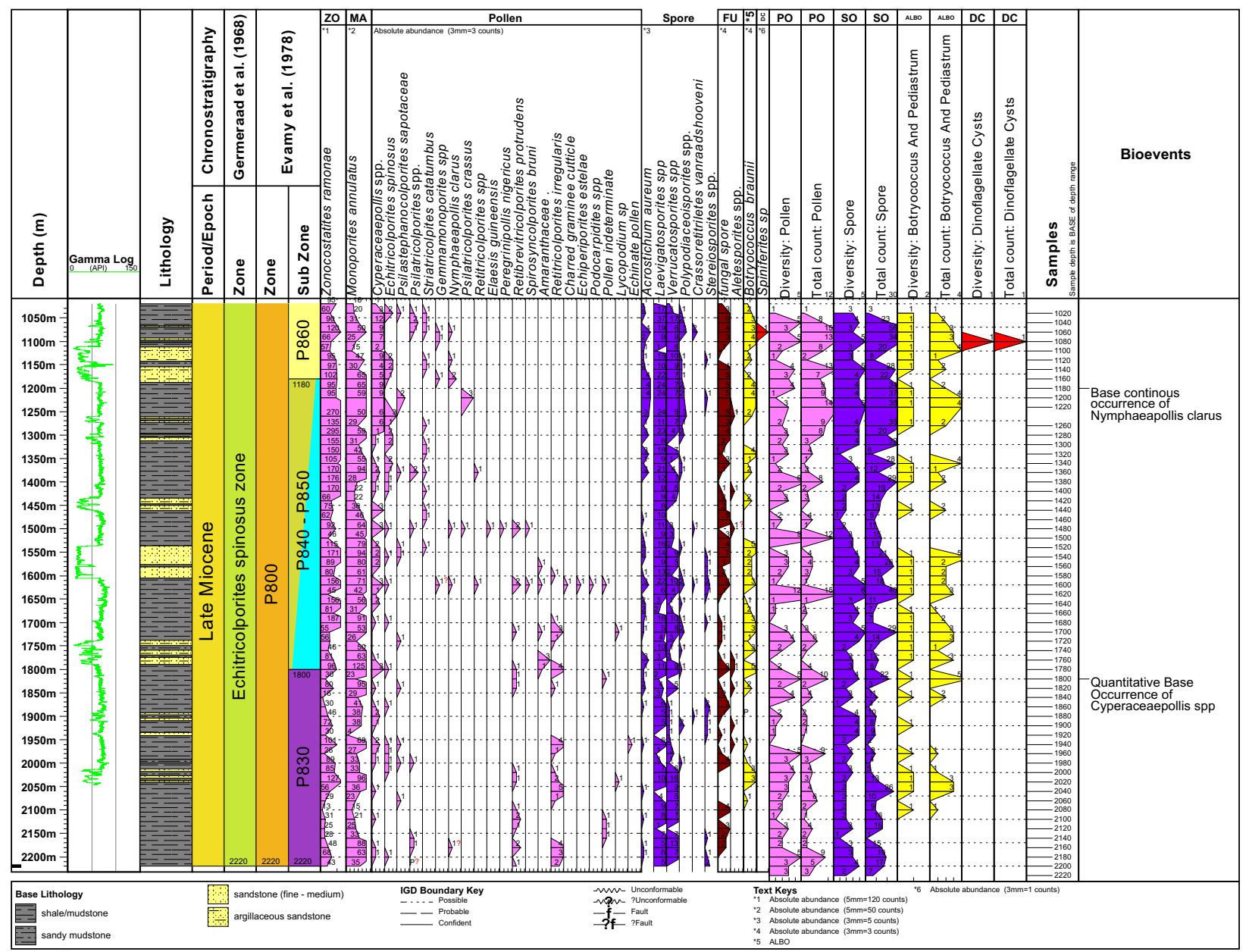

Figure 5: Palynomorphs Distribution and Zonation of Well Y.

$\begin{array}{lll}\text { Stratigraphic Interval } & : & 3165-2545 m \\ \text { Palynological Subrone } & : & \text { P840-P850 } \\ \text { Age } & : & \text { LateMiocene }\end{array}$

Definition:

The base of this composite subzone is defined by the quantitative base occurrence of Cyperaceaepollis sp. at $3165 \mathrm{~m}$. The top of the zone is marked by the base continuous occurrence of Nymphaeapollis clarus at depth $2545 \mathrm{~m}$.

Description:

The absence of the P840/P850 subzonal marker, Peregrinipollis nigericus, precludes the subdivision of the two subzones thereby resulting in the composite zone. Monoporites annulatus, Zonocostites ramonae, Laevigatosporites sp. and Verrucatosporites sp. constitute the dominant palynomorphs in this subzone. This association of palynomorphs recorded within this interval still suggests Late Miocene age.

$\begin{array}{lll}\text { Stratigraphic Interval } & : & 2545-2105 m \\ \text { Palynological Subrone } & : & \text { P860 } \\ \text { Age } & : & \text { LateMiocene }\end{array}$

\section{Definition:}

The subzonal base is marked by the base continuous occurrence of Nymphaeapollis clarus at depth $2545 \mathrm{~m}$ while the top of the zone probably lies shallower than the first sample analyzed at $2105 \mathrm{~m}$.

Description:

Abundant Monoporites annulatus, Zonocostites ramonae, Laevigatosporites sp. and Verrucatosporites sp. continue to dominate the palynofloral assemblage of this subzone. Cyperaceaepollis sp. and Retitricolporites irregularis exhibit rich occurrences. Nymphaeapollis clarus, Echitricolporites spinosus and Stereiosporites sp. show regular occurrences.

\section{WELL Y}

$\begin{array}{lll}\text { Stratigraphic Interval } & : & 2205-1800 m \\ \text { Palynological Subzone } & : & \text { P830 } \\ \text { Age } & : & \text { Late Miocene }\end{array}$

Definition:

The basal part of this oldest subzone is probably deeper than the last sample provided at $2205 \mathrm{~m}$. The zonal top is, however, placed at $1800 \mathrm{~m}$, the 
quantitative base occurrence of Cyperaceaepollis sp. Description:

The assemblage of this subzone is still dominated by abundant Monoporites annulatus, Zonocostites ramonae, Laevigatosporites sp. and Verrucatosporites sp. Cooccurring are Retitricolporites irregularis, Retibrevitricolporites protrudens, Stereisporites sp. and Echitricolporites spinosus. The recorded assemblage suggests a Late Miocene age for the interval.

$\begin{array}{lll}\text { Stratigraphic Interval } & : & 1800-1180 \mathrm{~m} \\ \text { Palynological Subzone } & : & \text { P840-P850 } \\ \text { Age } & : & \text { LateMiocene }\end{array}$

Definition:

The base of the composite subzone is defined by the quantitative base occurrence of Cyperaceaepollis sp. at depth $1800 \mathrm{~m}$. Its top is marked by the base continuous occurrence of Nymphaeapollis clarus at $1180 \mathrm{~m}$.

Description:

The absence of the P840/ P850 subzonal marker, Peregrinipollis nigericus, precludes the recognition of a boundary between the two subzones. This necessitated compositing the two subzones into one. Monoporites annulatus, Zonocostites ramonae, Laevigatosporites sp. and Verrucatosporites sp. continue to constitute the dominant palynomorphs of this subzone. Cyperaceaepollis sp., Acrostichum aureum and Botryococcus brannii were also recorded in appreciable numbers. Also, of significance is the presence of Echitricolporites spinosus, Stereiosporites sp., Retibrevitricolporites protrudens, Retitricolporites irregularis and Amaranthaceae. This assemblage suggests a possible Late Miocene age.

$\begin{array}{lll}\text { StratigraphicInterval } & : & 1180-1000 \mathrm{~m} \\ \text { Palynological Subrone } & : & \text { P860 } \\ \text { Age } & : & \text { LateMiocene }\end{array}$

\section{Definition:}

The zonal base of this youngest palynological zone penetrated in Well $\mathrm{Y}$ is defined at the base continuous occurrence of Nymphaeapollis clarus at depth $1180 \mathrm{~m}$. Its upper limit could not be defined as it is believed to be shallower than the first sample analyzed at $1000 \mathrm{~m}$.

Description:

The non-recovery of Retistephanolcolpites gracilis, the recognized P860/P870 boundary marker, in this well and in Well X confirmed that the wells are not younger than the Late Miocene. The assemblage within this subzone is still dominated by Monoporites annulatus, Zonocostites ramonae, Cyperaceaepollis sp., Laevigatosporites sp. and Verrucatosporites sp. Associated species recovered include Nymphaeapollis clarus, Echitricolporites spinosus, Acrostichum aureum and Botryococcus braunii. The palynomorph assemblage associated with this subzone indicates a Late Miocene age.

\section{Palynofacies Analysis and Paleoenvironment}

Palynofacies analysis was undertaken to assess the paleoenvironmental conditions under which the sequences in Well $\mathrm{X}$ and Well Y were deposited. From the count of 300 particulate organic matter recovered from each palynofacies slide, three main categories of morphological constituents were recognized. These are: Amorphous Organic Matter (AOM), Phytoclasts and Palynomorphs (sporomorph and phytoplankton). The percentage distribution of the particulate organic matter at different depths were determined and presented in Tables 1 and 2 for both Wells X and Y respectively. Plate 2 shows the light microscope photographs of selected amorphous organic matter, phytoclasts and palynomorphs from wells $\mathrm{X}$ and $\mathrm{Y}$.

Based on the relative abundance of these three groups and the results from the application of the Tyson (1993) ternary plot, three palynofacies assemblages were differentiated. These are Palynofacies Assemblage A (PF-A), Palynofacies Assemblage B (PF-B) and Palynofacies Assemblage $\mathrm{C}$ (PF-C).

\section{Palynofacies Assemblage A (PF-A)}

This palynofacies assemblage is dominated by 60 $96 \%$ AOM. The next significant representation of the palynofacies assemblage of this interval is taken by $3-35 \%$ phytoclasts. Palynomorphs constitute 1 $8 \%$ of the assemblage. This facies is equivalent to palynofacies type IX of Tyson (1993) that indicates a distal suboxic-anoxic condition (Figures 6 and 7).

\section{Palynofacies Assemblage B (PF-B)}

Palynofacies Assemblage B (PF-B) is made up of 23$58 \%$ while phytoclasts constitute $46-62 \%$ of the particulate organic matter. Palynomorphs make up about $1-10 \%$. The association of particulate organic matter in this palynofacies assemblage suggests similarities with kerogen type VI facies of Tyson (1993) that indicates a proximal suboxic-anoxic shelf environment (Figures 6 and 7). 
Table 1: Percentage of the different organic matter types (AOM, Phytoclasts and palynomorphs) as calculated from each sample in Well X.

\begin{tabular}{|c|c|c|c|}
\hline Depth (metres) & $\%$ AOM & \% Palynomorph & \% Phytoclasts \\
\hline $2105-2125$ & 11 & 1 & 88 \\
\hline $2125-2145$ & 60 & 1 & 39 \\
\hline $2145-2165$ & 51 & 1 & 48 \\
\hline $2165-2185$ & 28 & 2 & 70 \\
\hline $2185-2205$ & 52 & 1 & 47 \\
\hline $2205-2225$ & 26 & 1 & 73 \\
\hline $2225-2245$ & 60 & 1 & 39 \\
\hline $2245-2265$ & 22 & 1 & 77 \\
\hline $2265-2285$ & 9 & 1 & 90 \\
\hline $2285-2305$ & 56 & 1 & 43 \\
\hline $2305-2325$ & 65 & 1 & 34 \\
\hline $2325-2345$ & 47 & 1 & 52 \\
\hline $2345-2365$ & 8 & 2 & 90 \\
\hline $2365-2385$ & 9 & 1 & 90 \\
\hline $2385-2405$ & 9 & 1 & 90 \\
\hline $2405-2425$ & 65 & 1 & 34 \\
\hline $2425-2445$ & 9 & 1 & 90 \\
\hline $2445-2465$ & 48 & 1 & 51 \\
\hline $2465-2485$ & 45 & 6 & 49 \\
\hline $2485-2505$ & 51 & 2 & 47 \\
\hline $2505-2525$ & 35 & 5 & 60 \\
\hline $2525-2545$ & 65 & 1 & 34 \\
\hline $2545-2565$ & 29 & 1 & 70 \\
\hline $2565-2585$ & 65 & 1 & 34 \\
\hline $2585-2605$ & 65 & 1 & 34 \\
\hline $2605-2625$ & 65 & 1 & 34 \\
\hline $2625-2645$ & 55 & 2 & 43 \\
\hline $2645-2665$ & 90 & 1 & 9 \\
\hline $2665-2685$ & 85 & 1 & 14 \\
\hline $2685-2705$ & 55 & 2 & 43 \\
\hline $2665-2685$ & 85 & 1 & 14 \\
\hline $2705-2725$ & 65 & 1 & 34 \\
\hline $2725-2745$ & 55 & 1 & 34 \\
\hline $2745-2765$ & 65 & 3 & 32 \\
\hline $2765-2785$ & 65 & 1 & 34 \\
\hline $2785-2805$ & 55 & 2 & 43 \\
\hline $2805-2825$ & 45 & 3 & 42 \\
\hline $2825-2845$ & 34 & 1 & 65 \\
\hline $2845-2865$ & 55 & 1 & 44 \\
\hline $2865-2885$ & 55 & 3 & 42 \\
\hline $2885-2905$ & 53 & 1 & 46 \\
\hline $2905-2925$ & 34 & 1 & 45 \\
\hline $2925-2945$ & 79 & 1 & 20 \\
\hline $2945-2965$ & 65 & 1 & 34 \\
\hline $2965-2985$ & 65 & 1 & 34 \\
\hline $2985-3005$ & 65 & 5 & 30 \\
\hline $3005-3025$ & 65 & 2 & 33 \\
\hline $3025-3045$ & 55 & 2 & 43 \\
\hline $3045-3065$ & 33 & 2 & 65 \\
\hline $3065-3085$ & 33 & 2 & 65 \\
\hline $3085-3105$ & 34 & 1 & 65 \\
\hline $3105-3125$ & 50 & 1 & 49 \\
\hline $3125-3145$ & 65 & 2 & 33 \\
\hline $3145-3165$ & 65 & 1 & 34 \\
\hline $3165-3185$ & 34 & 1 & 65 \\
\hline $3185-3205$ & 57 & 3 & 40 \\
\hline $3205-3225$ & 65 & 1 & 34 \\
\hline $3225-3245$ & 65 & 1 & 34 \\
\hline $3245-3265$ & 55 & 1 & 44 \\
\hline $3265-3285$ & 56 & 1 & 43 \\
\hline $3285-3305$ & 28 & 2 & 70 \\
\hline
\end{tabular}


Table 2: Percentage of the different organic matter types (AOM, Phytoclasts and palynomorphs) as calculated from each sample in Well Y.

\begin{tabular}{|c|c|c|c|}
\hline Depth (metres) & $\%$ AOM & $\%$ Palynomorph & $\%$ Phytoclasts \\
\hline $1000-1020$ & 90 & 2 & 8 \\
\hline $1020-1040$ & 90 & 2 & 8 \\
\hline $1040-1060$ & 96 & 1 & 3 \\
\hline $1060-1080$ & 90 & 2 & 8 \\
\hline $1080-1100$ & 92 & 1 & 7 \\
\hline $1100-1120$ & 65 & 5 & 30 \\
\hline $1120-1140$ & 62 & 8 & 30 \\
\hline $1140-1160$ & 65 & 7 & 28 \\
\hline $1160-1180$ & 54 & 10 & 36 \\
\hline $1180-1200$ & 70 & 2 & 28 \\
\hline $1200-1220$ & 30 & 5 & 65 \\
\hline $1240-1260$ & 65 & 8 & 27 \\
\hline $1260-1280$ & 62 & 8 & 30 \\
\hline $1280-1300$ & 24 & 6 & 70 \\
\hline $1300-1320$ & 65 & 2 & 33 \\
\hline $1320-1340$ & 27 & 10 & 63 \\
\hline $1340-1360$ & 20 & 5 & 75 \\
\hline $1360-1380$ & 57 & 10 & 33 \\
\hline $1380-1400$ & 20 & 5 & 75 \\
\hline $1400-1420$ & 23 & 2 & 75 \\
\hline $1420-1440$ & 65 & 5 & 30 \\
\hline $1440-1460$ & 60 & 2 & 38 \\
\hline $1460-1480$ & 32 & 8 & 60 \\
\hline $1480-1500$ & 58 & 6 & 46 \\
\hline $1500-1520$ & 29 & 1 & 70 \\
\hline $1520-1540$ & 54 & 1 & 45 \\
\hline $1540-1560$ & 35 & 8 & 57 \\
\hline $1560-1580$ & 37 & 5 & 58 \\
\hline $1580-1600$ & 60 & 5 & 35 \\
\hline $1600-1620$ & 34 & 1 & 65 \\
\hline $1620-1640$ & 54 & 6 & 40 \\
\hline $1640-1660$ & 65 & 5 & 30 \\
\hline $1660-1680$ & 37 & 3 & 65 \\
\hline $1680-1700$ & 38 & 2 & 60 \\
\hline $1700-1720$ & 34 & 1 & 70 \\
\hline $1720-1740$ & 54 & 3 & 43 \\
\hline $1760-1780$ & 23 & 5 & 72 \\
\hline $1780-1800$ & 20 & 8 & 72 \\
\hline $1800-1820$ & 70 & 6 & 24 \\
\hline $1820-1840$ & 30 & 10 & 60 \\
\hline $1840-1860$ & 92 & 1 & 7 \\
\hline $1860-1880$ & 78 & 2 & 20 \\
\hline $1880-1900$ & 70 & 2 & 28 \\
\hline $1900-1920$ & 57 & 2 & 41 \\
\hline $1920-1940$ & 90 & 1 & 9 \\
\hline $1940-1960$ & 90 & 1 & 9 \\
\hline $1960-1980$ & 33 & 7 & 60 \\
\hline $1980-2000$ & 37 & 6 & 57 \\
\hline $2000-2020$ & 30 & 2 & 68 \\
\hline $2020-2040$ & 26 & 4 & 70 \\
\hline $2040-2060$ & 29 & 1 & 70 \\
\hline $2060-2080$ & 18 & 2 & 80 \\
\hline $2080-2100$ & 50 & 3 & 47 \\
\hline $2100-2120$ & 53 & 2 & 45 \\
\hline $2120-2140$ & 57 & 1 & 42 \\
\hline $2140-2160$ & 70 & 2 & 28 \\
\hline $2160-2180$ & 22 & 1 & 77 \\
\hline $2180-2200$ & 18 & 2 & 80 \\
\hline $2200-2220$ & 19 & 1 & 80 \\
\hline
\end{tabular}


Palynofacies Assemblage C (PF-C)

Phytoclasts, with percentage representation of between $65-80 \%$, dominate this assemblage. AOM, hitherto, the dominant palynodebris in the preceding assemblages, comes next with percentage representation of $18-38 \%$.
Palynomorphs constitute $1-10 \%$ of the palynofacies. This facies corresponds to palynofacies type II of Tyson (1993) indicating a marginal dysoxic-anoxic condition (Figures 6 and 7).

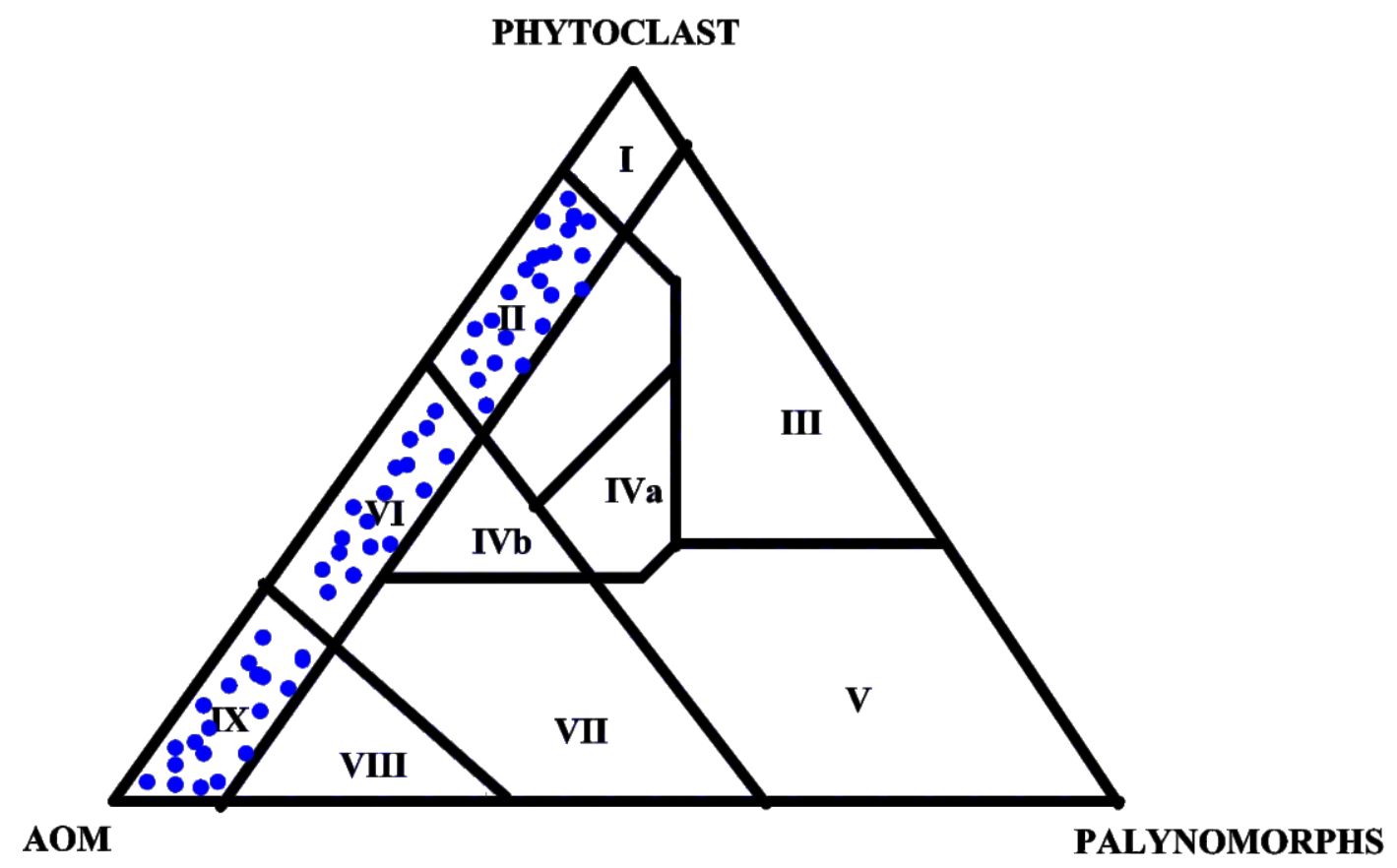

Figure 6: Paleoenvironment diagram illustrating palynofacies and palynological groups used for paleoenvironmental interpretation for well X (After'Tyson, 1993).

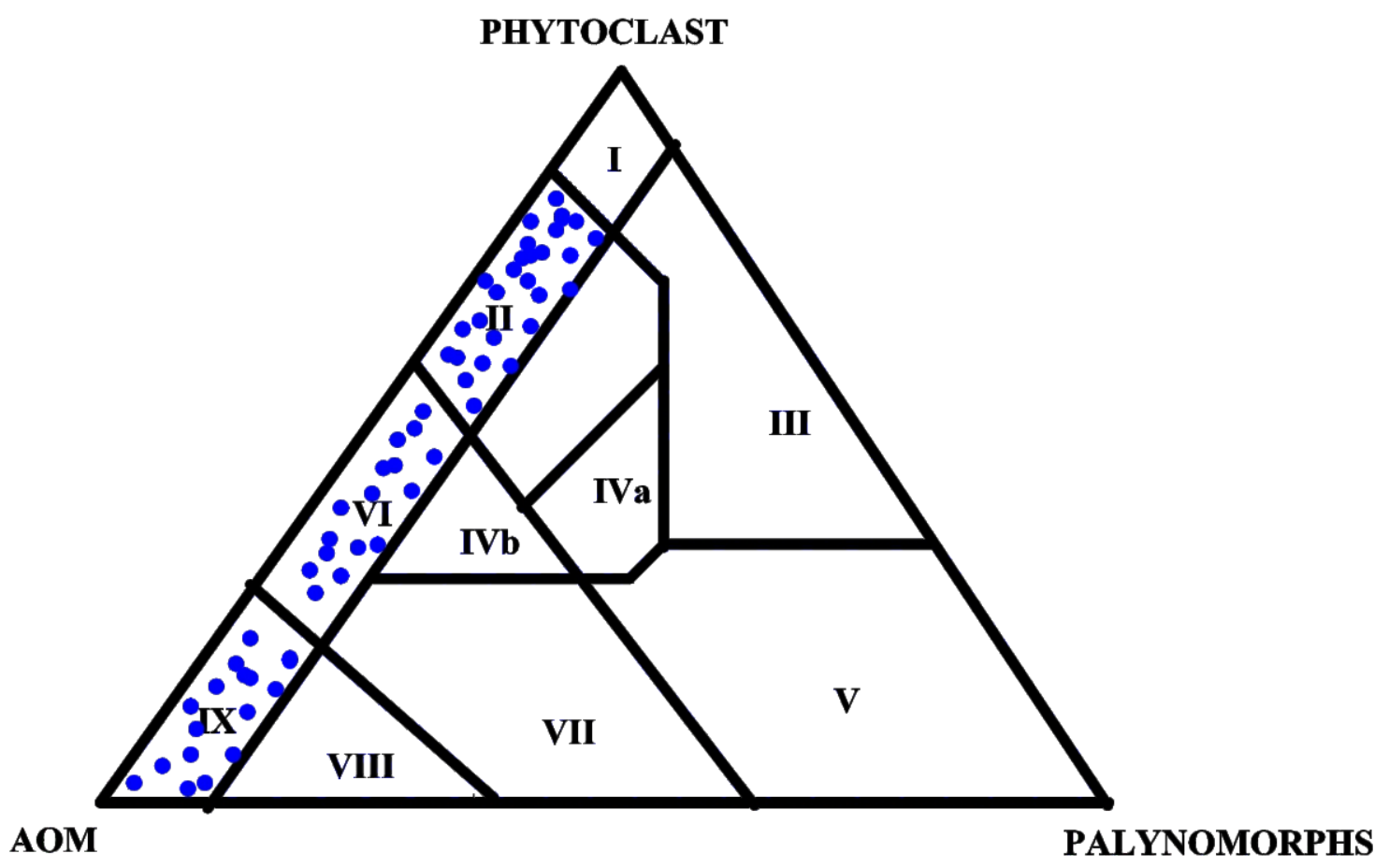

Figure 7: Paleoenvironment diagram illustrating palynofacies and palynological groups used for paleoenvironmental interpretation for well Y (After Tyson, 1993). 


\section{Paleoenvironment}

The paleoenvironmental interpretation inferred for the studied sections of Well X and Well Y was based on the integration of palynofacies and palynomorphs information interpreted from the analysis. The different environments identified are discussed as follows:

\section{Distal suboxic - anoxic Environment.}

This is the deepest environment of deposition among the three identified palynofacies assemblages observed in both wells. Palynofacies Assemblage A corresponds to Palynofacies Type IX on the Tyson's (1993) ternary diagram. This environment was recognized in Well $\mathrm{X}$ within intervals $2305-2325 \mathrm{~m}, 2405-2425 \mathrm{~m}, 2525$ $2545 \mathrm{~m}, 2565-2585 \mathrm{~m}, 2585$ - $2605 \mathrm{~m}, 2605-$ $2625 \mathrm{~m}, 2645-2665 \mathrm{~m}, 2665$ - $2685 \mathrm{~m}, 2705-$ $2725 \mathrm{~m}, 2745-2765 \mathrm{~m}, 2765$ - $2785 \mathrm{~m}, 2925-$ $2945 \mathrm{~m}, 2945$ - $2965 \mathrm{~m}, 2965$ - $2985 \mathrm{~m}, 2985-$ $3005 \mathrm{~m}, 3005-3025 \mathrm{~m}, 3125-3145 \mathrm{~m}, 3145-$ $3165 \mathrm{~m}, 3205-3225 \mathrm{~m}$ and $3225-3245 \mathrm{~m}$. This same environment was found within intervals $1000-1160 \mathrm{~m}, 1180-1200 \mathrm{~m}, 1240-1280 \mathrm{~m}$, $1300-1320 \mathrm{~m}, 1420-1460 \mathrm{~m}, 1580-1600 \mathrm{~m}$, 1640 - $1660 \mathrm{~m}, 1800-1820 \mathrm{~m}, 1840-1900 \mathrm{~m}$, $1920-1960 \mathrm{~m}$ and $2140-2160 \mathrm{~m}$ in Well Y. This is the deepest environment of deposition among the three identified palynofacies types observed in both wells.

The high record of AOM associated with this assemblage suggests reducing conditions and increase water column resulting in dysoxic or anoxic bottom conditions according to Kholeif and Ibrahim (2010). The dominance of amorphous organic matter (AOM) indicates long distance sediments transportation further away from land into nearshore/marine environment (transitional environment) (Atta-Petters et al., 2013).

A brackish or lagoonal environment of deposition has been suggested by Carvalho et al. (2006) for high concentration of amorphous organic matter in the sediment. This environment is rich in terrestrially derived palynomorphs of wellpreserved and some degraded palynomorphs indicating that the assemblages are from several sources. Zonocostites ramonae is dominant with common presence of coastal environments species such as pteridophyte spores: Verrucatosporites sp. and Laevigatosporites sp. The presence of a singular occurrence of Spiniferites sp. suggests sporadic influx of marine water.

\section{Proximal suboxic-anoxic shelf Environment.}

This environment was recognized in Well $\mathrm{X}$ within interval $2125-2165 \mathrm{~m}, 2185-2205 \mathrm{~m}, 2225-$ 2245 m, 2285 - 2305 m, 2325 - 2345 m, 2445 $2525 \mathrm{~m}, 2625$ - 2645m, 2685 - $2705 \mathrm{~m}, 2725$ 2745 m, 2785 - 2825 m, 2845 - 2925 m, 3025 $3045 \mathrm{~m}, 3105-3125 \mathrm{~m}, 3185-3205 \mathrm{~m}$ and $3265-$ $3285 \mathrm{~m}$. The environment was also found within intervals $1160-1180 \mathrm{~m}, 1360-1380 \mathrm{~m}, 1460-$ $1500 \mathrm{~m}, 1520$ - $1580 \mathrm{~m}, 1620$ - $1640 \mathrm{~m}, 1660$ $1680 \mathrm{~m}, 1720$ - $1740 \mathrm{~m}, 1760$ - $1780 \mathrm{~m}, 1900-$ $1920 \mathrm{~m}, 1980-2000 \mathrm{~m}$ and $2080-2140 \mathrm{~m}$ in Well Y. The intervals are designated as Palynofacies Assemblage B and correspond to Palynofacies Type VI on the Tyson's (1993) ternary diagram (Figures 6 and 7). The environment extended from distal suboxic-anoxic basin towards proximal suboxic-anoxic shelf.

This environment is characterized by the high amorphous preservation due to reducing basin conditions. The increasing proportion of the phytoclasts content suggests proximity to source or turbidity input. Most of the phytoclasts are translucent woody material rather than opaque varieties. The observed increasing trend in the percentage composition of phytoclasts and the gradual reduction in that of $\mathrm{AOM}$ indicate paleoenvironmental shift toward more proximal depositional conditions close to the source of vegetation (Tyson, 1993). The low proportion of opaque phytoclasts suggests low salinity due to close proximity to active fluvio-deltaic sources (Kholeif and Ibrahim, 2010). Martinez et al., (2008) attribute this observation to proximal conditions (prodelta environment). This facies represents nearshore marine facies (suboxic shelf-proximal anoxic) with low energy. The abundant occurrence of Zonocostites ramonae in the recovered palynomorph assemblages of the wells is indicative of accumulation of sediments from the proximal to mangrove swamp. Laevigatosporites sp. and Verrucatosporites sp. are the other coastaldweller represented. 
Marginal dysoxic - anoxic basin Environment.

Palynofacies Assemblage C, recognized between intervals $2105-2125 \mathrm{~m}, 2165-2185 \mathrm{~m}, 2205-$ 2225 m, 2245 - 2285 m, 2345 - 2405 m, 2425 $2445 \mathrm{~m}, 2545$ - $2565 \mathrm{~m}, 2865$ - $2885 \mathrm{~m}, 3045-$ $3105 \mathrm{~m}, 3165-3185 \mathrm{~m}$ and $3285-3305 \mathrm{~m}$ in Well $\mathrm{X}$ and also recognized within intervals 1200 $1220 \mathrm{~m}, 1280-1300 \mathrm{~m}, 1320-1360 \mathrm{~m}, 1380-$ $1420 \mathrm{~m}, 1500-1520 \mathrm{~m}, 1600-1620 \mathrm{~m}, 1680$ $1720 \mathrm{~m}, 1740$ - $1760 \mathrm{~m}, 1780$ - $1800 \mathrm{~m}, 1820$ $1840 \mathrm{~m}, 1960-1980 \mathrm{~m}, 2000-2080 \mathrm{~m}$ and 2160 $2220 \mathrm{~m}$ in Well Y represents Palynofacies Type II on the Tyson's (1993) ternary diagram (Figures 6 and 7).

The assemblage is dominated by abundant phytoclast. The phytoclast are represented by both translucent and opaque elements of equal dimension which indicates a marginal and shallow proximal environment. The low representation of amorphous organic matter is indicative of low oxygen content. The palynomorphs assemblage is dominated by Zonocostites ramonae with other coastal swamp species such as Verrucatosporites sp. and Laevigatosporites sp. Fungal elements are present while the absence of marine elements further supports the interpreted proximal environment.

The identified palynofacies types observed in both wells shows fluctuations between the three interpreted environments (distal suboxic - anoxic, Proximal suboxic-anoxic shelf and Marginal dysoxic - anoxic basin environment). This is also partially reflected in the lithology which shows alternations of sand and shale sequences with varying percentage of the shale and sand percentages as seen in the lithology column of figures 4 and 5 .

\section{WELL CORRELATION}

A correlation of Wells $\mathrm{X}$ and $\mathrm{Y}$ sequences was attempted on the basis of the recorded bioevents and the zones. The two wells' sections have been found to correlate to each other (Figure 8). The correlation which is on the basis of the zonal boundaries also helps to establish equivalent sand bodies within the studied sections of the wells.

\section{CONCLUSIONS}

The studied sections of Wells $\mathrm{X}$ and $\mathrm{Y}$ yielded fairly rich and diverse palynomorphs assemblage comprising of pollen, spores and freshwater algae. This facilitated the subdivision of the well sections into zones and subzones following the Evamy et al. (1978) zonation schemes. The two wells sections fall within the P800 zone subdivided into the P830, P840-P850 and P860 subzones of Evamy et al. (1978) on the basis of the occurrence of characteristic palynomorph taxa such as Nymphaeapollis clarus, and Cyperaceaepollis sp. and other associated palynomorphs. A late Miocene age is assigned to the studied section of the two wells.

The organic facies analysis revealed three palynofacies assemblages (A, B, and C) which indicate three distinct paleoenvironments. Palynofacies Assemblage A (PF-A) was characterized by the dominance of amorphous organic matter (AOM) with few phytoclasts and low palynomorphs suggesting a distal suboxic to anoxic basin paleoenvironment. Palynofacies Assemblage B (PF-B) was characterized by a gradual decreasing amorphous organic matter followed by increasing proportion of phytoclast and low palynomorphs. A proximal suboxic to anoxic paleoenvironment was proposed for this palynofacies type. Palynofacies Assemblage C (PF-C) was characterized by abundant phytoclast with reduced percentage of amorphous organic matter (AOM) and moderate proportion of palynomorphs. A marginal dysoxic - anoxic paleoenvironment was inferred for this assemblage. On the basis of the recognized palynofacies assemblages, environment shoaling from marginal marine to coastal deltaic setting was proposed for the sedimentary sequence penetrated by the two wells. 


\section{Acknowledgement}

The authors wish to appreciate the support from the management and members of staff of Crystal Age Limited and GEC Energy Solutions Limited for their assistance during the research work. We are grateful to the anonymous reviewer who painstakingly went through the manuscript for the refinement of the work.

\section{REFERENCES}

Adegoke, O. S. 2002. High Resolution Biostratigraphy, Sequence Stratigraphy and 3-D Modelling: Indispensable Tools for E \& P Activities in the New Millenium. Nigerian Association of Petroleum Explorationists Bulletin 16(1), 46-65.

Allen, J. R. L. 1965. Late Quaternary Niger Delta and adjacent areas: sedimentary environments and lithofacies. American Association of Petroleum Geologists Bulletin 49, $547-600$.

Atta-Peters, D., Agama, C. I., Asiedu, D.K. and Apesegah, E. 2013. Palynology, palynofacies and paleoenvironments of sedimentary organic matter from Bonyere - Well, Tano basin, Western Ghana. International Letters of Natural Sciences 5, 27 45.

Avbovbo, A. A. (1978). Tertiary lithostratigraphy of Niger Delta. American Association of Petroleum Geologists Bulletin 62(2), 295-300.

Batten, D. J. 1982. Palynofacies, palaeoenvironments and petroleum. Journal of Micropalaeontology 1,107-114.

Batten, D. J. and Stead, D. T. 2005. Palynofacies analysis and its stratigraphic application. In: Koutsoukos, E. A. M. (Ed.), Applied Stratigraphy. Springer Dordrecht, Netherlands,pp. 203-226.

Burke, K., Dessauvagie, T. J. F. and Whiteman, A. J. 1972. Geological history of the Benue valley. In: Dessauvagie, T. F. J. and Whiteman, A. J. (Eds.), African Geology, University Press, Ibadan, 187-206.

Carvalho, M. A., Filho, J. G. M. and Menezes, T. R. 2006. Palynofacies and sequence stratigraphy of the Aptian-Albian of the Sergipe Basin, Brazil. Sedimentary Geology $192(5), 57-74$.

Christopher, R. A. and Goodman, D. K. 1996. Introduction to biostratigraphy and time scales. In: Jansonius, J. and McGregor, D. C. (Ed.), Palynology: principles and applications; American Association of Stratigraphic Palynologists Foundation 2, 463 492.

Combaz, A. 1964. Les palynofaciès. Revue de Micropaléontologie 7, 205-18.

Combaz, A. 1980. Les kerogenes vus au microscope. In: Durand, B. (Ed.), Kerogen - insoluble organic matter from sedimentary rocks, Paris, Editions Technip, p. 55-111.

Doust, H. and Omatsola, E. 1990. Niger Delta. In: Edwards, J. D. and Santogrossi, P. A. (Eds.), Divergent / Passive Margin Basins. AAPG Memoir 48, 201-238.

Ejedawe, J. E. 1981. Patterns of incidence of oil reserves in Niger Delta basin. American Association of Petroleum Geologists Bulletin 65, 1574-1585.

Ekweozor, C. M. and Daukoru, E. M. 1984. Petroleum source-bed evaluation of Tertiary Niger Delta - reply. American Association of Petroleum Geologists Bulletin 68, 390-394.

Evamy, D. D., Haremboure, J., Kemerling, P., Knaap, W. A., Molly, F. A. and Rowlands, P. H. 1978. Hydrocarbon Habitat of Tertiary Niger Delta. American Association of Petroleum Geologist Bulletin 62, 1-39.

Faegri, K. and Iversen, J. 1989. Pollen Analysis. In: Faegri, K., Kaland, P. E., Krzywinski, K, (Eds). New York: John Wiley \& Sons, New York. 328 pp.

Frankl, E. J. and Cordry, E. A. 1967. The Niger delta oil province: Recent developments onshore and offshore. Seventh World Petroleum Congress Proceedings, Mexico 2, 195 -209 .

Germeraad, J. H., Hopping, C. A. and Muller, J. 1968. Palynology of Tertiary sediments from tropical areas. Review of Palaeobotany and Palynology 6, 189-348.

Hospers, J. 1971. The geology of the Niger Delta area. In: Delany, F. M. (Ed.), The geology of Eastern Atlantic Continental Margin, Great Britain Institute of Geological Science Report 70 (16), $121-142$.

Kholeif, S. H. E. and Ibrahim, M. I. 2010. Palynofacies Analysis of Inner Continental Shelf and Middle Slope 


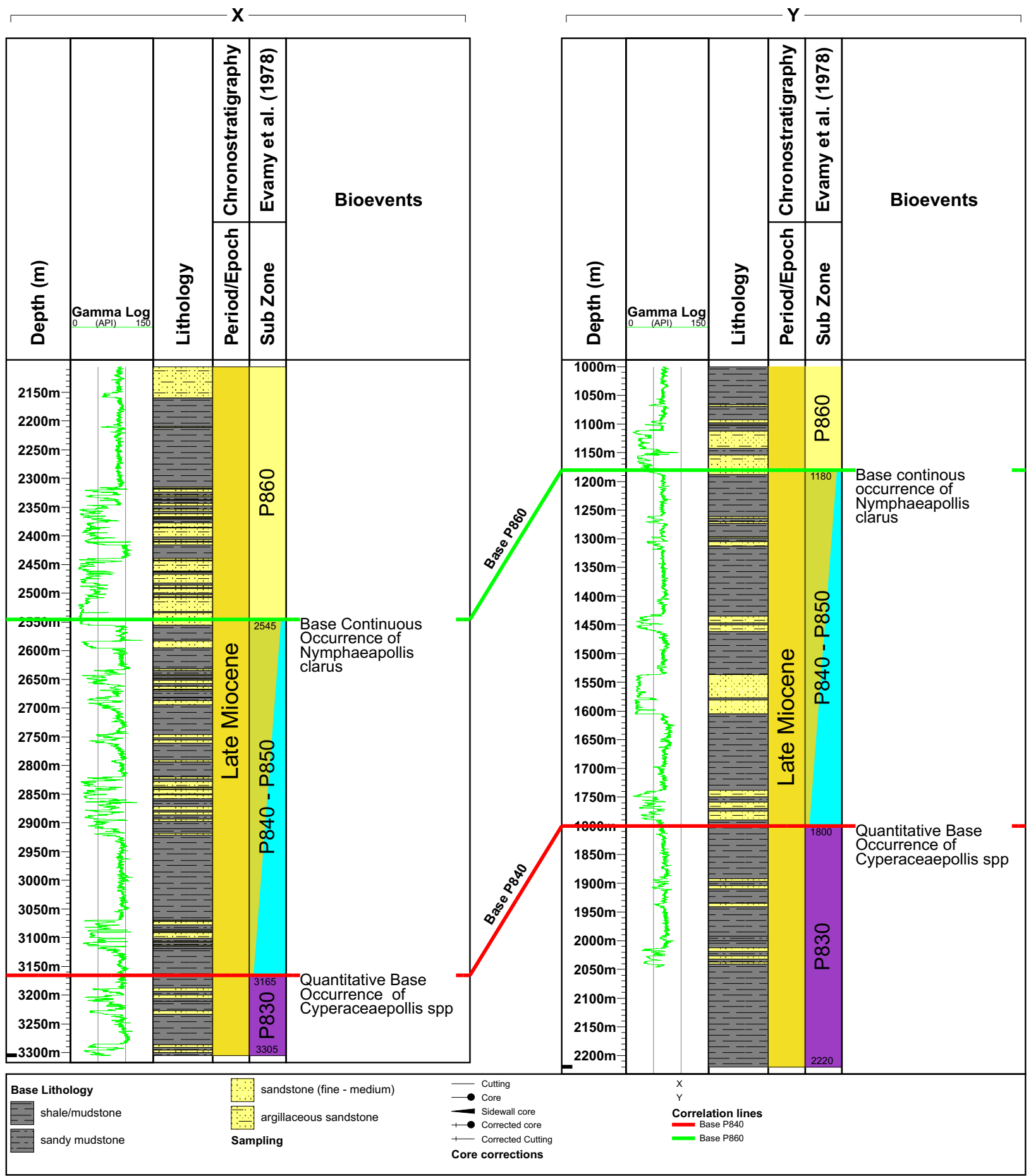

Figure 8: A correlation of the sequences of Wells $\mathrm{X}$ and $\mathrm{Y}$ based on the recognized biozones. 
Sediments offshore Egypt, South-eastern Mediterranean. Geobios 43, 333-347.

Kulke, H. 1995. Nigeria. In: Kulke, H. (Ed.), Regional Petroleum Geology of the World, Part II, Africa, America, Australia and Antarctica: Berlin, Gebruder Borntraeger, 143-172.

Martinez, M. A., Pramparo, M. B., Quattrocchio, M. E. and Zavala, C. A. 2008. Depositional environment and hydrocarbon potential of the Middle Jurassic Los Molles Formation, Neuquen Basin, Argentina: palynofacies and organic geochemical data. Revista Geologica de Chile 35(2), 279-305.

Oboh, F. E. 1995. Sedimentological and palynological characteristics of E2.0 reservoir (Middle Miocene) in the Kolo Creek Field, Niger Delta. In: Oti, M.N. and Postuma, G. (Eds.), Geology of Deltas, Rotterdam/Brookfield, A. A. Balkema, 243-256.

Oboh, F. E., Salami, M. B. and Chapman, J. L. 1992. Palynological interpretation of the palaeoenvironments of Miocene strata of the well Igbomoturu-1, Niger Delta. Journal of Micropalaeontology 11,1-6.

Odedede, O., Lucas, F. A. and Asuen, G. O. 2012. Sequence Stratigraphic and Palaeoenvironmental Studies of Palynoflora from E-12 Well, Offshore Niger Delta. Journal of Mining and Geology 48(2), 185-198.

Oyede, A. C. 1992. Palynofacies in deltaic stratigraphy. Nigerian Association of
Petroleum Explorationists Bulletin 7(1), 10-16. Powell, A. J., Dodge, J. D. and Lewis, J. 1990. Late Neogene to Plesitocene palynological facies of Peruvian continental margin upwelling, Leg 112. In: Suess, E., Von Huene, R. (Eds.), Proceedings of the Ocean Drilling Project, Scientific Results, College Station, Texas, 112, 297321.

Rocanglia, L. and Kuijpers, A. 2006. Revision of the palynofacies model of Tyson (1993) based on recent high-latitude sediments from the North Atlantic. Facies 52, 19-39).

Short, K. C. and Stauble, A. J. 1967. Outline of the Geology of Niger Delta. American Association of petroleum Geologists Bulletin 51, $761-779$.

Stonely, R. 1966. The Niger Delta region in the light of the theory of continental drift. GeologicalMagarine 105, 385-397.

Traverse, A. 2008. Paleopalynology. (2 ${ }^{\text {nd }}$ Edition) Springer, Dordrecht, The Netherlands, 813 pp.

Tyson, R. V. 1993. Palynofacies analysis. In: Jenkins, D.G. (Ed.), Applied Micropaleontology, Kluwer Academic Publishers. The Netherlands, Amsterdam, pp. 153-191.

Tyson, R. V. 1995. Sedimentary organic matter. Organic facies and palynofacies. Chapman and Hall, London, xviii +615 p., 6 pl.

Whiteman, A. J. 1982. Niger Delta: Its Petroleum geology, resources and potential. Graham and Trotman, London. 2 Volumes. 


\section{PLATE 1}
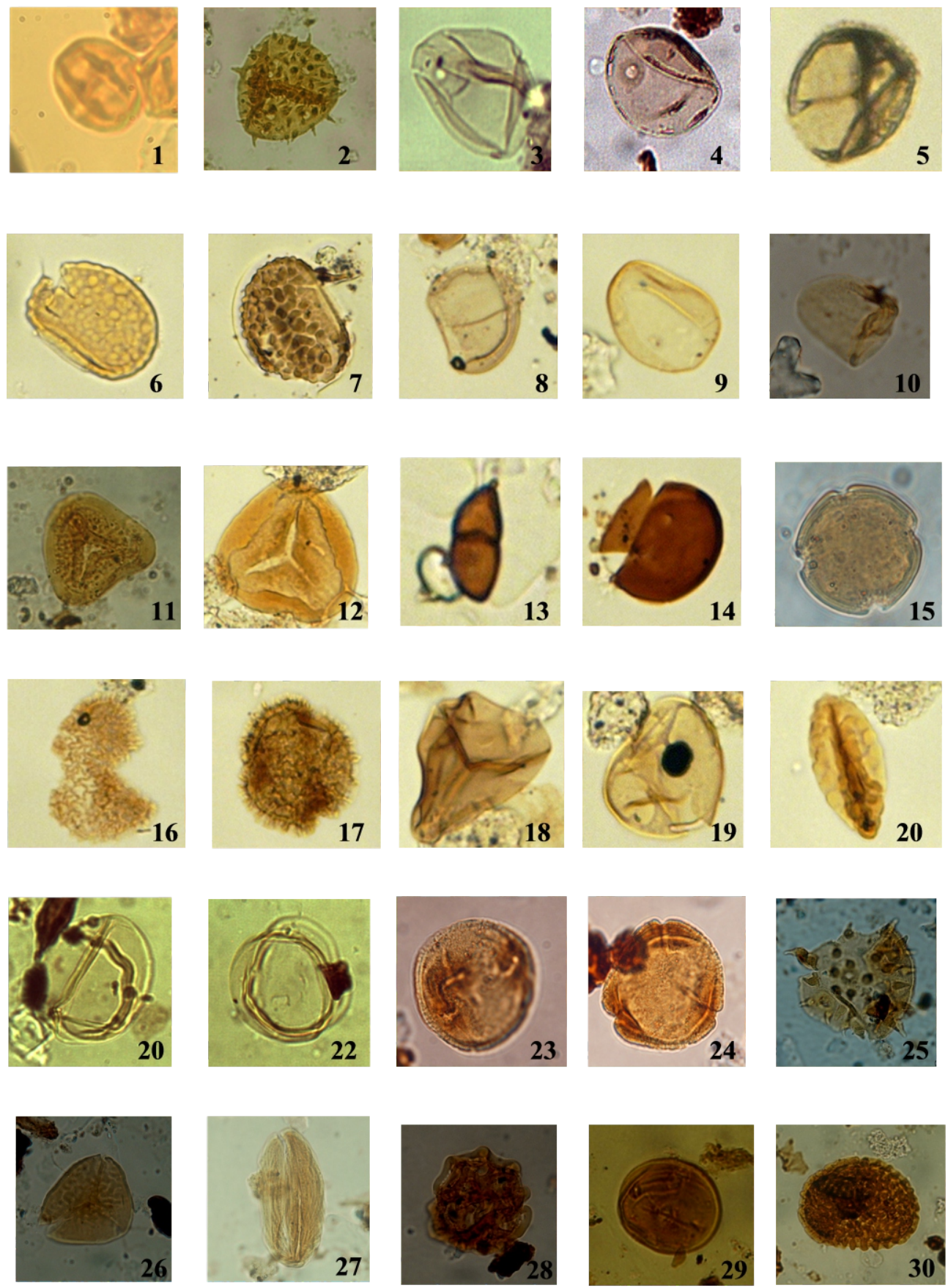

$600 \mu \mathrm{m}$

\section{PLATE 1}

Figure

2

$3-4$

5

6-7Verrucatosporites sp.

8-9 Laevigatosporites sp.

10 Cyperaceaepollis sp.

$11-12$ Polypodiaceoisporites sp. (Pteris sp.)

13-14 Fungal spore
Zonocostites ramonae

Echiperiporites estelae

Monoporites annulatus

Stereiosporites sp.
15 Pachydermites diederixi

$16-17$ Retitricolporites irregularis

18 - 19 Acrostichum aureum

20 Gemmamonoporites sp.

21 - 22 Nymphaeapollis clarus

23-24 Psilatricolporites crassus

25 Echiperiporites estelae.

26 Lycopodium sp.

27 Striatricolpites catatumbus

28. Peregrinipollis nigericus

29 Psilastephanocolporites sapotaceae 


\section{PLATE 2}
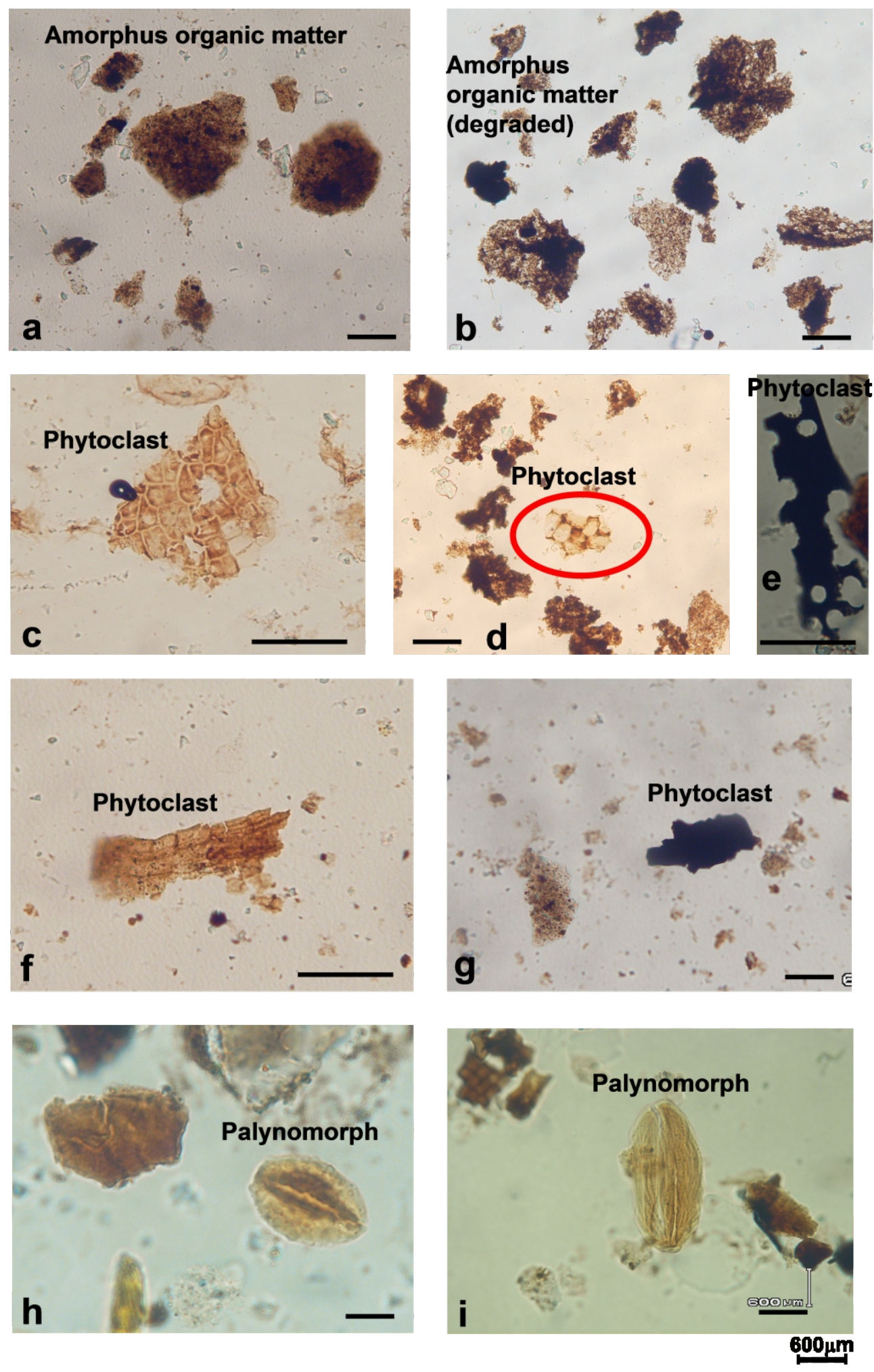

PLATE 2

Light microscope photographs of selected amorphous organic matter, phytoclasts and palynomorphs from wells $\mathrm{X}$ and Y. (a-b) Particles of brown to dark brown amorphous organic matter (AOM) with the presence of inclusions with (b) showing degraded AOM. Both a and b shows irregularly shape structureless material of probable algenite or resinous cortex. (c) Epidermal cuticle (d) Epidermal cuticle (circled) in a groundmass of AOM. $(e, g)$ Structured, opaque, black phytoclasts (Charcoal). (f)Platy-like structured phytoclast with regular cell outlines (Tracheid). (b-i) Palynomorphs. 